\title{
OPEN Author Correction: Lower Extremity Joint Contributions to Trunk Control During Walking in Persons with Transtibial Amputation
}

Adam J. Yoder, Amy Silder, Shawn Farrokhi, Christopher L. Dearth \& Brad D. Hendershot

Correction to: Scientific Reports https://doi.org/10.1038/s41598-019-47796-z, published online 22 August 2019

The original version of this Article contained an error in the spelling of the name of the author Amy Silder, which was incorrectly given as Amy B. Silder. This has now been corrected in the PDF and HTML versions of the Article, and in the accompanying Supplementary Material file.

(c) (i) Open Access This article is licensed under a Creative Commons Attribution 4.0 International License, which permits use, sharing, adaptation, distribution and reproduction in any medium or format, as long as you give appropriate credit to the original author(s) and the source, provide a link to the Creative Commons license, and indicate if changes were made. The images or other third party material in this article are included in the article's Creative Commons license, unless indicated otherwise in a credit line to the material. If material is not included in the article's Creative Commons license and your intended use is not permitted by statutory regulation or exceeds the permitted use, you will need to obtain permission directly from the copyright holder. To view a copy of this license, visit http://creativecommons.org/licenses/by/4.0/.

(c) The Author(s) 2019 